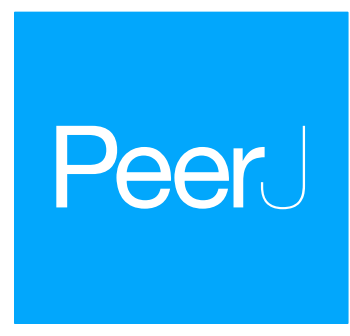

Submitted 27 February 2018

Accepted 3 July 2018

Published 10 October 2018

Corresponding author Adekemi Titilayo Adesulu-Dahunsi, adesuluchemmy@yahoo.com

Academic editor

Carlos Conte-Junior

Additional Information and Declarations can be found on page 18

DOI 10.7717/peerj.5326

Copyright

2018 Adesulu-Dahunsi et al.

Distributed under

Creative Commons CC-BY 4.0

OPEN ACCESS

\section{Production of exopolysaccharide by strains of Lactobacillus plantarum YO175 and OF101 isolated from traditional fermented cereal beverage}

\author{
Adekemi Titilayo Adesulu-Dahunsi ${ }^{1}$, Kumaraswamy Jeyaram ${ }^{2}$, \\ Abiodun Isiaka Sanni ${ }^{1}$ and Kolawole Banwo ${ }^{1}$ \\ ${ }^{1}$ Department of Microbiology, University of Ibadan, Ibadan, Oyo, Nigeria \\ ${ }^{2}$ Microbial Resource Division, Institute of Bioresources and Sustainable Development, Imphal, Manipur, \\ India
}

\section{ABSTRACT}

Lactobacillus plantarum YO175 and OF101 isolates from Nigerian traditional fermented cereal gruel 'ogi', were investigated on the basis of their capability to produce exopolysaccharide (EPS) on sucrose modified deMan Rogosa Sharpe medium (mMRS). Functional groups analysis of the EPSs produced (EPS-YO175 and EPS-OF101) by Fourier-transform infrared (FT-IR) spectroscopy revealed the presence of $-\mathrm{OH}, \mathrm{C}=\mathrm{O}$ and $\mathrm{C}-\mathrm{H}$ groups. The chemical composition of EPS-YO175 and EPS-OF101 showed the presence of $87.1 \%$ and $80.62 \%$ carbohydrates and $1.21 \%$ and $1.47 \%$ protein. For maximum EPS yield, three significant factors were optimized using central composite design and response surface methodology, the predicted maximum EPS produced was $1.38 \mathrm{~g} / \mathrm{L}$ and $2.19 \mathrm{~g} / \mathrm{L}$, while the experimental values were $1.36 \mathrm{~g} / \mathrm{L}$ and $2.18 \mathrm{~g} / \mathrm{L}$ for EPSYO175 and EPS-OF101. The EPS samples showed strong antioxidant activities in-vitro. The scale-up of the production process of the EPS will find its potential application in food industries.

Subjects Biotechnology, Food Science and Technology, Microbiology, Molecular Biology Keywords Ogi, Lactobacillus plantarum, Exopolysaccharide, FT-IR, Antioxidant.

\section{INTRODUCTION}

The ability of various lactic acid bacteria (LAB) to produce extracellular long-chain polysaccharides/exopolysaccharides which consists of branched and repeating units of sugars in varied ratios have been reported (Pan \& Mei, 2010; Wang et al., 2010; Li et al., 2014; Imran et al., 2016). The EPS produced have immense commercial importance because of the industrially beneficial physico-chemical properties they exhibit and GRAS (generally recognized as safe) status of the LAB from which they are secreted (Surayot et al., 2014). Exopolysaccharide produced by LAB play essential roles in improving the mouth feel, texture, and rheology of fermented food preparations. They also serve as food additives, prebiotics and demonstrate useful physiological effects such as anticarcinogenecity, antitumor, immunomodulating activities and as blood cholesterol-lowering agents in humans (Kim et al., 2010). 
Many indigenous foods produced in Nigeria are usually fermented before consumption (Adesulu \& Awojobi, 2014). Lactic acid bacteria are commonly isolated from Nigerian indigenous fermented foods and beverages (Banwo, Sanni \& Tan, 2013; Sanni \& Adesulu, 2013; (Adesulu-Dahunsi, Sanni \& Jeyaram, 2017). Ogi is a popular non-alcoholic fermented cereal beverage that is processed by natural fermentation with the dominance of LAB. It forms a staple food of the people in West Africa, especially among the south-western Nigerian where it serves as weaning food in infants and/or breakfast beverage among the adults. Exopolysaccharides produced by some of the LAB isolated from these fermented food products have been documented to improve the food texture and quality. Exopolysaccharides producing LAB such as Streptococcus thermophilus, Lactobacillus delbrueckii subsp. bulgaricus, Lactococcus lactis subsp. cremoris isolated from dairy products and fermented milk have been extensively studied (Patel \& Prajapati, 2013).

Different species of LAB, especially Lactobacillus plantarum have been reported to produce EPS (Wang et al., 2010; Imran et al., 2016). L. plantarum perform important fermentative roles during Nigerian traditional food preparation and provides positive health impacts which are strain specific, they exhibit an outstanding effect on the flavour and texture of these foods, with specific metabolic and technological properties, such as production of EPS (Adesulu-Dahunsi et al., 2017). Recently, researchers have reported that EPS produced from LAB species have antioxidant activities and are non-toxic; these characteristics are of great importance and may replace the synthetic antioxidants (Li et al., 2013; Zhang et al., 2013; Abdhul et al., 2014). Exopolysaccharides produced by Lactobacillus species improves sourdough properties by aiding water absorption, improving its structure, thereby prolonging shelf life of the fermented foods. Few works have been reported on EPS producing ability of LAB strains isolated from cereals-based fermented food (Torres-Rodríguez et al., 2014; Adesulu-Dahunsi et al., 2018; Adesulu-Dahunsi, Jeyaram, \& Sanni, 2018).

Optimization of the growth factors and media composition are criteria to be considered for maximal EPSs production by LAB strains (Zajseket, Gorsek \& Kolar, 2013; AdesuluDahunsi, Sanni \& Jeyaram, 2018). The statistical designs used in this study to determine the optimal conditions for the EPS production are central composite design (CCD) and response surface methodology (RSM). The objective of this study was to improve the production of EPS from L. plantarum strains and to evaluate the antioxidant activities in vitro. The factors affecting the production of EPS from L. plantarum YO175 and OF101 were analyzed, and three significant variables (cultivation time, $\mathrm{pH}$ and sucrose concentration) were chosen to optimize the production conditions using CCD and RSM. In addition, the in vitro antioxidant assays of the EPS were also evaluated.

\section{MATERIAL AND METHODS Microorganisms and chemicals}

Two EPS-producing LAB strains isolated from ogi (Nigerian indigenous fermented cereal gruel from yellow and white maize varieties) were identified according to their biochemical characteristics and 16S rRNA gene sequencing as L. plantarum YO175 and L. plantarum 
OF101 (GenBank Accession numbers KU892395 and KU892393). DPPH, trichloroacetic acid (TCA), trifluoroacetic acid (TFA), Folin-Ciocalteu reagent, bovine serum albumin (BSA), phenol, concentrated sulfuric acid, methanol, ferric chloride, potassium ferric cyanide, pyrogallol, ascorbic acid, glucose, galactose, rhamnose, xylose, fructose and ribose (Sigma Chemical Ltd., St. Louis, USA).

\section{Extraction and purification of EPS}

The isolation and partial purification of the EPS samples were performed as previously described by Savadogo et al. (2004), and modified by Adesulu-Dahunsi et al. (2018) with mMRS broth as the cultivation medium as it support the growth of $L$. plantarum species and MRS as growth medium for all LAB species. Briefly, L. plantarum YO175 and L. plantarum OF101 were propagated in 1,000 mL MRS modified sucrose broth (glucose was replaced with sucrose) and incubated for $24 \mathrm{~h}$ in an incubator shaker, the L. plantarum cultures were heated at $100{ }^{\circ} \mathrm{C}$ for $10 \mathrm{~min}$, then centrifuged at $12,000 \times \mathrm{g}$ for $15 \mathrm{~min}$ to remove the cells, the supernatants was precipitated with double volume ice-cold ethanol, shaken vigorously and centrifuged at $5,000 \times \mathrm{g}$ for $30 \mathrm{~min}$ at $4{ }^{\circ} \mathrm{C}$. The pellets obtained were dried to a constant weight in an oven at $50{ }^{\circ} \mathrm{C}$. The resulting pellets were mixed with ultrapure water, the EPS slurry was precipitated with double volume of cold ethanol, this step was repeated three times in order to eliminate any cells debris that may be present. The EPS was mixed with minimal water and dialyzed against distilled water using $10 \mathrm{kDa}$ membranes for $48 \mathrm{~h}$ at $4{ }^{\circ} \mathrm{C}$ with the changing of the water twice daily. The partially purified EPS obtained from dialysis was frozen at $-20^{\circ} \mathrm{C}$ in deep freezer. The frozen EPS was covered with parafilm and were lyophilized for 2 days and the resulting EPS samples were preserved for further characterization.

\section{Molecular mass determination}

The molecular mass of the EPS-YO175 and EPS-OF101 were determined on an Agilent 1100HPLC system equipped with a TSK-GEL G3000SWxl column $(7.5 \times 300 \mathrm{~mm}$, Tosoh Corp., Tokyo, Japan) and a refractive index detector (RID). The column was eluted with $0.1 \mathrm{M} \mathrm{Na}_{2} \mathrm{SO}_{4}$ solution at a flow rate of $0.8 \mathrm{~mL} \mathrm{~min}^{-1}$. Molecular mass was estimated from the standard graph which was plotted using standard dextrans (Sigma-Aldrich, USA) (Pan \& Mei, 2010).

\section{Chemical composition analysis}

Total carbohydrates, total soluble protein content of the EPS samples, and lactic acid (LA) produced by the L. plantarum strains were determined.

The EPS samples were estimated using phenol-sulphuric acid method (Dubois et al., 1956). $1 \mathrm{~mL}$ of the EPS sample was added to $1 \mathrm{ml}$ of $5 \%$ cold phenol and $5 \mathrm{~mL}$ concentrated sulphuric acid placed in an ice bath, then incubated at room temperature for $20 \mathrm{~min}$ and the absorbance of the samples at $490 \mathrm{~nm}$ was taken using a spectrophotometer.

Estimation of the protein content was performed according to Lowry et al. (1951). To $1 \mathrm{~mL}$ EPS sample (s), $5 \mathrm{~mL}\left(2 \% \mathrm{Na}_{2} \mathrm{CO}_{3}\right.$ in $0.1 \mathrm{~N} \mathrm{NaOH}$ and $0.5 \% \mathrm{CuSO}_{4}$ in $1 \%$ potassium sodium tartrate in 50:1) was added and vortexed. The mixture was incubated at ambient 
temperature for $10 \mathrm{~min}, 0.5 \mathrm{~mL} 1 \mathrm{~N}$ Folin-Ciocalteau reagent was added and mixed and was kept in dark for 20 min after which the colour was measured at $660 \mathrm{~nm}$.

The production of LA in MRS broth by the L. plantarum strains was estimated. To $1 \mathrm{~mL}$ of the culture supernatants, $0.05 \mathrm{~mL}$ of $4 \% \mathrm{CuSO}_{4}$ and $6 \mathrm{~mL}$ of concentrated sulphuric acid was added and mixed well. The mixture was then incubated in boiling water bath for $10 \mathrm{~min}, 100 \mu \mathrm{L}$ of p-hydroxydiphenyl was added and kept in room temperature for $30 \mathrm{~min}$. The absorbance was measured at $560 \mathrm{~nm}$ (Salvucci, LeBlanc \& Perez, 2016).

\section{Analysis of monosaccharide composition}

The monosaccharide composition of the purified EPS samples was determined by thin layer chromatography (TLC) via aluminum plates coated with silica gel and high-performance liquid chromatography (HPLC) after hydrolysis of the EPS. Five milligram $5 \mathrm{mg}$ of the purified EPS sample (s) was dissolved in $0.5 \mathrm{~mL}$ MilliQ water and hydrolyzed in $0.5 \mathrm{~mL}$ of $6 \mathrm{~N}$ trifluoroacetic acid (TFA) at $100^{\circ} \mathrm{C}$ for $3 \mathrm{~h}$. The hydrolysate was evaporated to dryness at $50{ }^{\circ} \mathrm{C}$. Five microlitres $(5 \mu \mathrm{L})$ of the EPS samples were spotted onto a silica gel coated aluminum TLC plates. The mixed solvent (n-butanol, ethanol, and water (50:30:20 v/v/v) were used for separation of carbohydrates and standards, the fractions were visualized on the TLC plates, after dipping it in anisaldehyde-sulphuric acid reagent and heating the plates at $110^{\circ} \mathrm{C}$ for $30 \mathrm{~min}$. The EPS was also analyzed with HPLC system (Agilent 1100) equipped with Aqueous GPC start up Kit column and eluted with distilled water at a flow rate of $1.0 \mathrm{~mL} / \mathrm{min}$ at $20^{\circ} \mathrm{C}$. The separated components were monitored by a refractive index detector.

\section{Analysis of functional groups}

The infrared analysis of purified EPS from the two L. plantarum strains was carried out using an FT-IR spectrophotometer (Thermo Nicolet, USA) in the spectrum ranges of $400-4,000 \mathrm{~cm}^{-1}$ for the detection of functional groups present in the samples.

\section{Preliminary screening of cultivation condition and media composition for EPS production}

The optimal media composition and cultivation condition for EPS production in MRS broth were screened. The media components, carbon source $(20 \mathrm{~g} / \mathrm{L})$, organic nitrogen sources $(25 \mathrm{~g} / \mathrm{L})$, and inorganic nitrogen sources $(2 \mathrm{~g} / \mathrm{L})$, were substituted independently into the media and by keeping other components constant at different cultivation times $(12,24,36,48,60,72,84$ and $96 \mathrm{~h})$, initial $\mathrm{pH}$ of the media $(6,6.5,7,8)$ and different temperatures $\left(20,25,30,37\right.$ and $\left.45^{\circ} \mathrm{C}\right)$.

\section{In vitro determination of antioxidant properties}

The in-vitro antioxidant properties of the purified EPS samples (at $0.5-4 \mathrm{mg} / \mathrm{mL}$ concentration levels) were performed using standard methods.

The DPPH (1,1-diphenyl-2-picryl-hydrazyl) radical scavenging was measured according to the method of Rai et al. (2011). A $2.0 \mathrm{~mL}$ deionized water and $2.0 \mathrm{~mL}$ DPPH solution $(0.16 \mathrm{mM})$ were added to $1.0 \mathrm{~mL}$ EPS samples, the mixture was incubated at $37^{\circ} \mathrm{C}$ in a dark room for $30 \mathrm{~min}$. Absorbance (at $517 \mathrm{~nm}$ ) was measured against the blank. For the 
positive control, methanol was replaced with DPPH.

The DPPH radical (\%) scavenging activity $=1-(\mathrm{As}-\mathrm{Ab}) / \mathrm{Ac} \times 100$

As $=$ Absorbance of the EPS sample (s); Ab = Absorbance of blank; Ac $=$ Absorbance of control.

Superoxide scavenging activity of the EPS samples was performed according to Balakrishnan et al. (2011) published protocol. The mixture contained $0.3 \mathrm{~mL}$ of the EPS samples, $2.6 \mathrm{~mL}(50 \mathrm{mM})$ phosphate buffer at $\mathrm{pH} 8.2$ and $90 \mu \mathrm{L}$ of $3 \mathrm{mM}$ pyrogallol (dissolved in $10 \mathrm{mM} \mathrm{HCl}$ ). Then the absorbance (at $325 \mathrm{~nm}$ ) was taken at 0 min and $10 \mathrm{~min}$.

Superoxide scavenging activity $(\%)=1-\left(\mathrm{A}_{10}-\mathrm{A}_{0}\right) /\left(\mathrm{C}_{10}-\mathrm{C}_{0}\right) \times 100$

$\mathrm{A}_{0}$ absorbance of EPS sample (s) at $0 \mathrm{~min} ; \mathrm{A}_{10}$ absorbance of EPS sample (s) at $10 \mathrm{~min} ; \mathrm{C}_{0}$ absorbance of control at $0 \mathrm{~min} ; \mathrm{C}_{10}$ absorbance of control at $10 \mathrm{~min}$.

To measure the reducing power potential of the EPS samples, the following mixture; $100 \mu \mathrm{L}$ of the EPS sample, $900 \mu \mathrm{L}$ of phosphate buffer $(0.2 \mathrm{M}, \mathrm{pH} 6.6)$ and $900 \mu \mathrm{L}$ of $1 \%$ potassium ferric cyanide were incubated at $50{ }^{\circ} \mathrm{C}$ for $20 \mathrm{~min}$. Nine hundred microliters of TCA (10\%) was mixed with the solution and centrifuged at 5,000 $\times \mathrm{g}$ for $15 \mathrm{~min}$, then $900 \mu \mathrm{L}$ each of the supernatant solution, distilled water and $0.1 \%$ ferric chloride were mixed together. The solution was mixed together and the absorbance $(700 \mathrm{~nm})$ was taken (Balakrishnan et al., 2011).

The hydroxyl radical scavenging activity of the EPS samples was measured with the Fenton reaction. One milliliter $(1 \mathrm{~mL})$ of the EPS samples was added to the reaction mixture containing $1.0 \mathrm{~mL}$ of brilliant green $(0.435 \mathrm{mM}), 2.0 \mathrm{~mL}$ of $\mathrm{FeSO}_{4}(0.5 \mathrm{mM})$ and $1.5 \mathrm{~mL}$ of $\mathrm{H}_{2} \mathrm{O}_{2}\left(3.0 \%\right.$, w/v) and was incubated at $37^{\circ} \mathrm{C}$ for $20 \mathrm{~min}$, and the absorbance (at $624 \mathrm{~nm}$ ) was then measured (Balakrishnan et al., 2011).

The hydroxyl radical scavenging activity $(\%)=\left(\mathrm{As}-\mathrm{A}_{0}\right) /\left(\mathrm{A}-\mathrm{A}_{0}\right) \times 100$

$\mathrm{A}_{\mathrm{S}}=$ Absorbance of the sample; $\mathrm{A}_{0}=$ Absorbance of the control; $\mathrm{A}=$ Absorbance of deionized water without the sample and Fenton reaction.

\section{Statistical analysis}

All experiments were performed in triplicate and the results represented by their mean $\pm \mathrm{SD}$. Tests of significant differences were determined by Duncan's Multiple Range Test at $(P<0.05)$. For maximum EPS production, Design-Expert software version 8.0.7.1 (StatEase Inc., Minneapolis, USA) was used for the experimental designs and regression analysis of the experimental data. Statistical analysis of the model was performed to evaluate the analysis of variance (ANOVA) and and its statistical significance was determined by $F$-test. 


\section{RESULTS}

\section{Molecular mass of the EPS}

Based on the calibration curve of the elution retention time of various dextran standards used, the molecular mass of EPS-YO175 and EPS-OF101 was estimated to be $1.2 \times 10^{6} \mathrm{Da}$ and $4.4 \times 10^{5} \mathrm{Da}$.

\section{Chemical composition analysis of the EPS}

Total carbohydrate content in EPS-YO175 was $87.1 \%$ and $80.62 \%$ for EPS-OF101. The total soluble protein showed low protein content of approximately $1.21 \%$ and $1.47 \%$ for EPS-YO175 and EPS-OF101. The lactic acid produced by L. plantarum YO175 and OF101 was $13.6 \pm 0.1 \mathrm{mg} / \mathrm{mL}$ and $11.4 \pm 0.15 \mathrm{mg} / \mathrm{mL}$, respectively.

\section{Analysis of monosaccharide composition}

The TLC analysis of the EPS samples was compared with the sugar standards, and their retention time values revealed that EPS-YO175 composed of glucose and galactose and EPS-OF101 showed only glucose (Fig. S1).

The retention time of the EPS samples was compared with the reference standards in the HPLC analysis; this also confirmed that the EPS samples contained glucose and galactose (Fig. 1).

\section{Analysis of functional groups of the EPS}

The FTIR spectrum of the EPS samples revealed that the polysaccharides contained a significant number of $\mathrm{O}-\mathrm{H}$ group representing vibration of the hydroxyl groups of carbohydrate showed by broad stretching in the region $3,288 \mathrm{~cm}^{-1}$ and $3,276 \mathrm{~cm}^{-1}$. The stretching bands around the $2,924 \mathrm{~cm}^{-1}$ and $2,898 \mathrm{~cm}^{-1}$ region were due to $\mathrm{C}-\mathrm{H}$ stretching vibration. The absorptions around $1,655 \mathrm{~cm}^{-1}$ and $1,649 \mathrm{~cm}^{-1}$ were due to stretching vibration of carbonyl group $(\mathrm{C}=\mathrm{O})$. The bands observed around $1,159 \mathrm{~cm}^{-1}$ in EPS-YO175 and $1,150 \mathrm{~cm}^{-1}$ in EPS-OF101 were attributed to the vibration of C-O-C bond (Fig. 2).

\section{Preliminary screening of cultivation condition and media composition}

Among the different carbon sources, the highest EPS yield was obtained for the sucrose supplemented MRS broth in L. plantarum YO175 (1.59 $\pm 0.06 \mathrm{~g} / \mathrm{L})$ and OF101 $(1.07 \pm 0.01$ $\mathrm{g} / \mathrm{L}$ ). Also at $20 \mathrm{~g} / \mathrm{L}$ sucrose concentration, the EPS yield obtained for both $L$. plantarum strains were; $1.64 \pm 0.11$ and $1.05 \pm 0.02 \mathrm{~g} / \mathrm{L}$ respectively. Yeast extract was the most effective among the nitrogen sources screened, as the optimal EPS yield obtained were $1.63 \pm 0.05 \mathrm{~g} / \mathrm{L}$ and $1.01 \pm 0.02 \mathrm{~g} / \mathrm{L}$ in L. plantarum YO175 and OF101. Ammonium sulphate showed optimal EPS yield in both strain; L. plantarum YO175 $(1.56 \pm 0.02 \mathrm{~g} / \mathrm{L})$ and OF101 $(1.00 \pm 0.02 \mathrm{~g} / \mathrm{L})$. The optimal temperature and $\mathrm{pH}$ for the EPS production was $30^{\circ} \mathrm{C}$ and $\mathrm{pH} 7.0$ respectively with the corresponding EPS $(\mathrm{g} / \mathrm{L})$ yield $(1.56,1.03$; and $1.72 ; 1.10$ ) (Table 1). The dry EPS samples are shown in Fig. S2. 
$\mathrm{mV}$

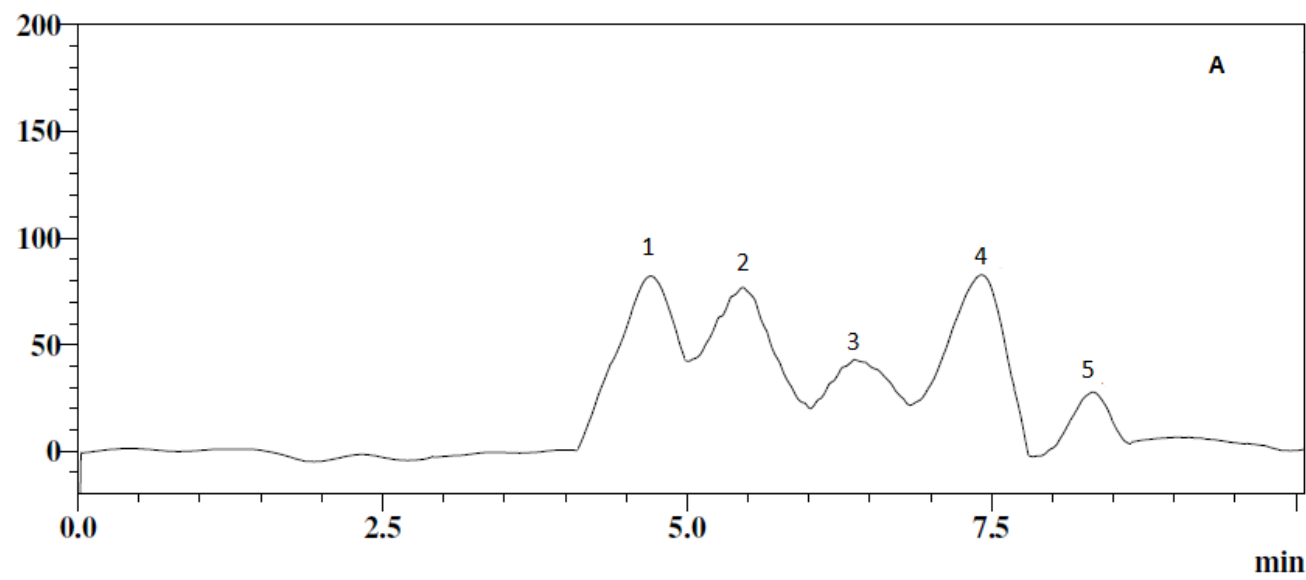

$\mathrm{mV}$

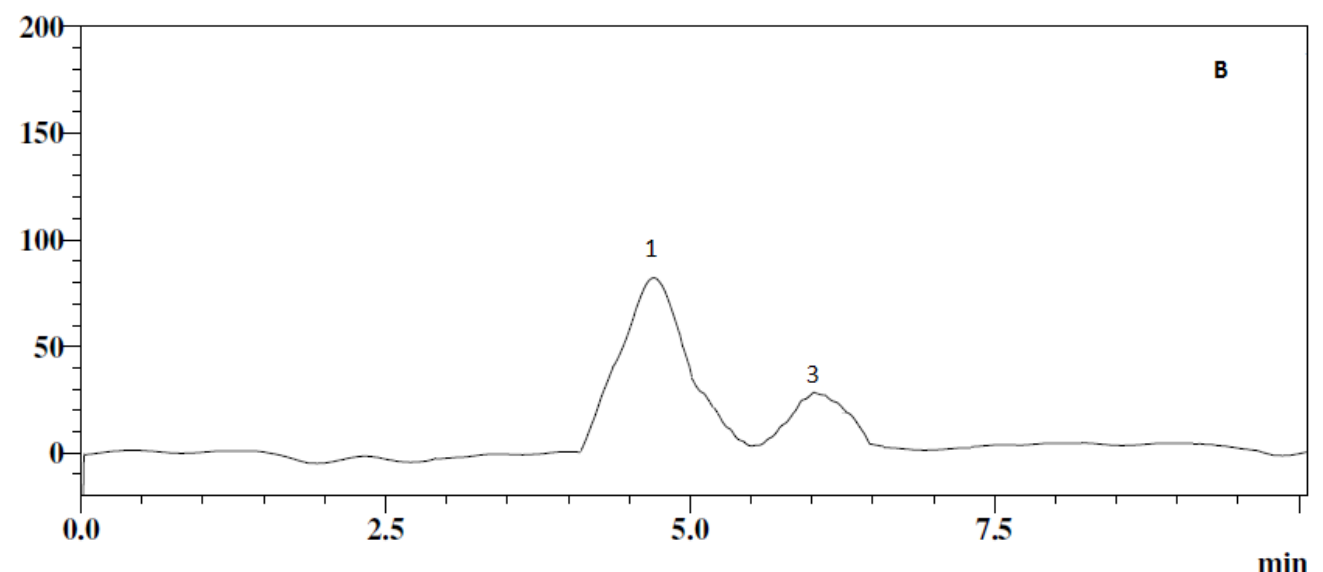

$\mathrm{mV}$

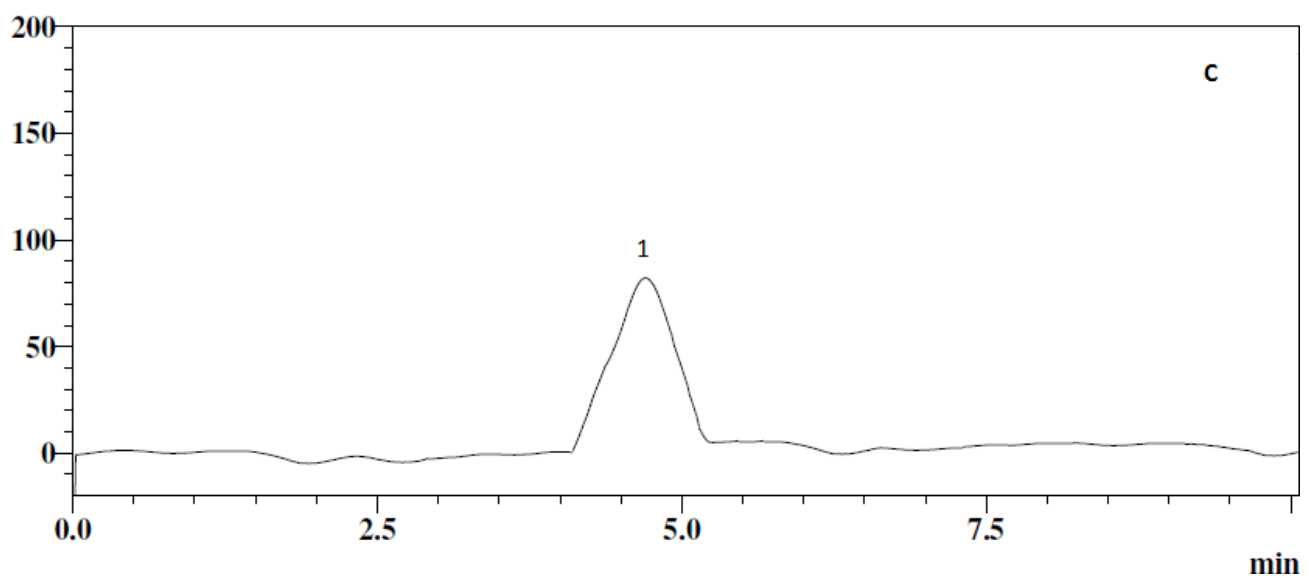

Figure 1 HPLC chromatograms of the EPS samples and standards. (A) standards, (B) EPS-YO175, (C) EPS-OF101. The peaks correspond to glucose (peak 1), xylose (peak 2), galactose (peak 3), fructose (peak 4), rhamnose (peak 5). 

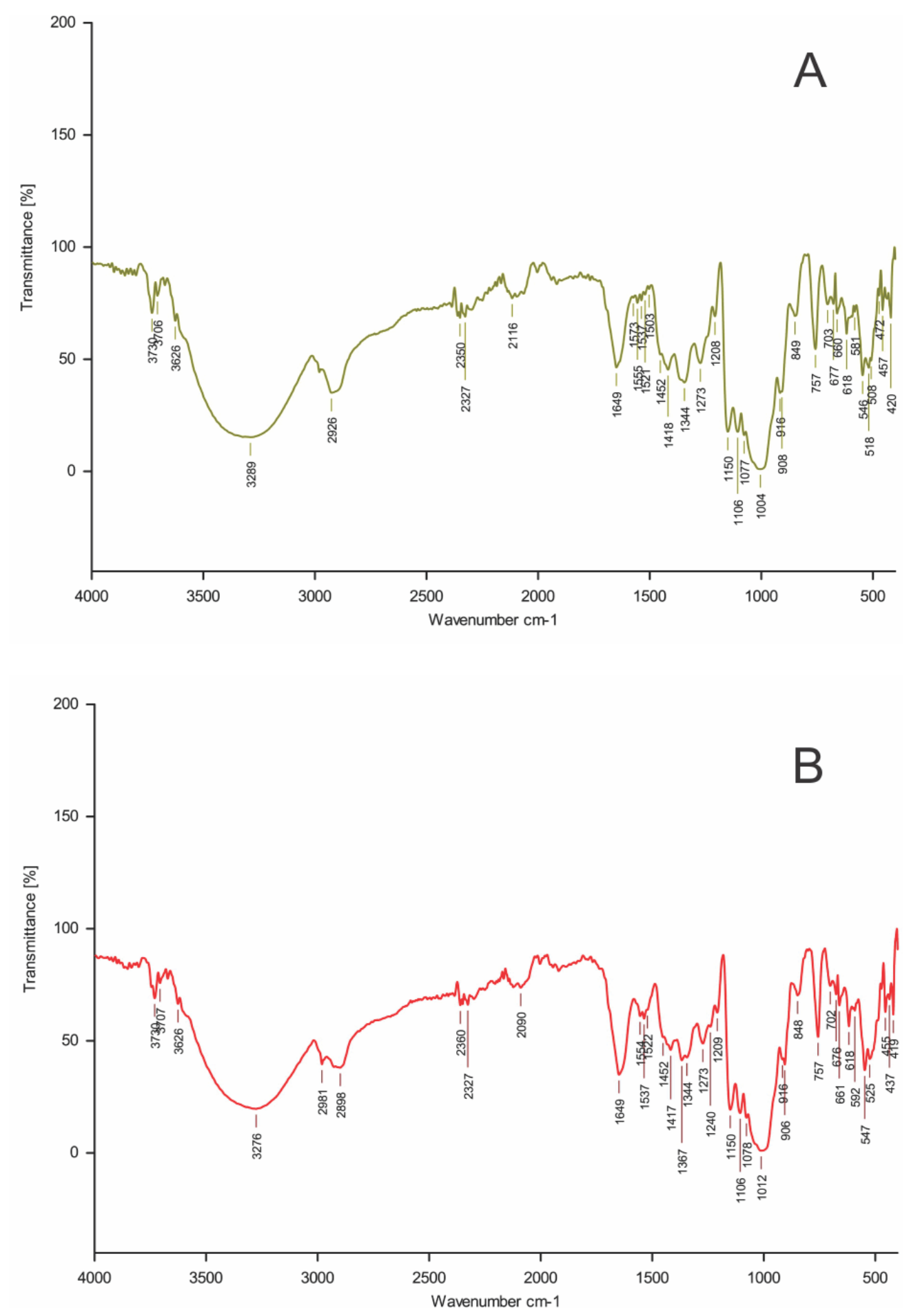

Figure 2 FTIR spectrum of EPS produced. (A) Lactobacillus plantarum YO175 (B) Lactobacillus plantarum OF101.

Full-size DOI: 10.7717/peerj.5326/fig-2 
Table 1 Effect of carbon sources, nitrogen sources, and cultivation conditions on exopolysaccharide production. The different carbon sources, organic and inorganic nitrogen and media composition, cultivation conditions were investigated.

Medium sources

\begin{tabular}{|c|c|c|}
\hline \multirow[t]{2}{*}{ Medium sources } & \multicolumn{2}{|c|}{ EPS yield (g/L) } \\
\hline & EPS-YO175 & EPS-OF101 \\
\hline \multicolumn{3}{|l|}{ Carbon sources $(20 \mathrm{~g} / \mathrm{L})$} \\
\hline Glucose & $0.94 \pm 0.10$ & $0.62 \pm 0.44$ \\
\hline Sucrose & $1.59 \pm 0.10$ & $1.07 \pm 0.26$ \\
\hline Lactose & $1.48 \pm 0.14$ & $1.03 \pm 0.17$ \\
\hline Galactose & $0.87 \pm 0.26$ & $0.41 \pm 0.26$ \\
\hline \multicolumn{3}{|c|}{ Sucrose concentrations (g/L) } \\
\hline 10 & $1.13 \pm 0.20$ & $0.90 \pm 0.62$ \\
\hline 20 & $1.64 \pm 0.44$ & $1.05 \pm 0.44$ \\
\hline 30 & $1.52 \pm 0.26$ & $0.71 \pm 0.56$ \\
\hline 40 & $1.45 \pm 0.75$ & $0.62 \pm 0.17$ \\
\hline 50 & $1.10 \pm 0.00$ & $0.36 \pm 0.10$ \\
\hline \multicolumn{3}{|c|}{ Organic nitrogen $(25 \mathrm{~g} / \mathrm{L})$} \\
\hline Yeast extract & $1.63 \pm 0.07$ & $1.01 \pm 0.11$ \\
\hline Beef extract & $1.15 \pm 0.22$ & $0.82 \pm 0.10$ \\
\hline Tryptone & $1.48 \pm 0.31$ & $0.83 \pm 0.24$ \\
\hline Peptone & $1.61 \pm 0.01$ & $0.77 \pm 0.20$ \\
\hline \multicolumn{3}{|c|}{ Inorganic nitrogen $(2 \mathrm{~g} / \mathrm{L})$} \\
\hline Ammonium sulphate & $1.56 \pm 0.10$ & $1.00 \pm 0.00$ \\
\hline Ammonium nitrate & $1.51 \pm 0.00$ & $0.80 \pm 0.00$ \\
\hline Ammonium chloride & $1.48 \pm 0.21$ & $0.71 \pm 0.10$ \\
\hline Tri-ammonium citrate & $1.37 \pm 0.32$ & $0.75 \pm 0.12$ \\
\hline Sodium nitrite & $1.30 \pm 0.10$ & $0.68 \pm 0.26$ \\
\hline Potassium nitrate & $1.15 \pm 0.24$ & $0.72 \pm 0.18$ \\
\hline \multicolumn{3}{|l|}{ Temperature $\left({ }^{\circ} \mathrm{C}\right)$} \\
\hline 20 & $0.53 \pm 0.20$ & $0.20 \pm 0.01$ \\
\hline 25 & $0.77 \pm 0.01$ & $0.31 \pm 0.08$ \\
\hline 30 & $1.56 \pm 0.10$ & $1.03 \pm 0.11$ \\
\hline 37 & $1.50 \pm 0.18$ & $0.80 \pm 0.00$ \\
\hline 45 & $0.46 \pm 0.24$ & $0.10 \pm 0.10$ \\
\hline \multicolumn{3}{|l|}{ Cultivation time (h) } \\
\hline 12 & $0.30 \pm 0.06$ & $0.10 \pm 0.04$ \\
\hline 24 & $1.70 \pm 0.08$ & $0.76 \pm 0.10$ \\
\hline 36 & $1.66 \pm 0.24$ & $1.00 \pm 0.12$ \\
\hline 48 & $1.68 \pm 0.20$ & $1.08 \pm 022$ \\
\hline 60 & $1.50 \pm 0.10$ & $1.02 \pm 0.24$ \\
\hline 72 & $1.38 \pm 0.07$ & $0.72 \pm 0.11$ \\
\hline 84 & $1.17 \pm 0.04$ & $0.66 \pm 0.22$ \\
\hline 96 & $1.00 \pm 0.30$ & $0.60 \pm 0.32$ \\
\hline
\end{tabular}

EPS yield (g/L)

(continued on next page) 
Table 1 (continued)

\begin{tabular}{lcc} 
Medium sources & \multicolumn{2}{c}{ EPS yield $(\mathrm{g} / \mathrm{L})$} \\
\cline { 2 - 3 } & EPS-YO175 & EPS-OF101 \\
\hline pH & & \\
6.0 & $1.51 \pm 0.11$ & $0.65 \pm 0.01$ \\
6.5 & $1.60 \pm 0.00$ & $1.01 \pm 0.01$ \\
7.0 & $1.72 \pm 0.24$ & $1.10 \pm 0.02$ \\
8.0 & $1.50 \pm 0.33$ & $0.82 \pm 0.07$ \\
\hline
\end{tabular}

Notes.

Values are means of three independent experiments (mean \pm SD).

Table 2A The central composite experimental design matrix showing the predicted and experimental values of exopolysaccharide from Lactobacillus plantarum YO175. The CCD of the EPS samples.

\begin{tabular}{llllll} 
Run & A & B & C & \multicolumn{2}{c}{ EPS Yield $(\mathbf{g} / \mathbf{L})$} \\
\cline { 5 - 6 } & $\begin{array}{l}\text { Cultivation } \\
\text { time }(\mathbf{h r})\end{array}$ & $\begin{array}{l}\text { Sucrose } \\
\text { concentration }(\mathbf{g})\end{array}$ & $\mathbf{p H}$ & Experimental $($ E1) & Predicted \\
\hline 1 & 45.48 & 24.00 & 6.99 & 1.28 & 1.22 \\
2 & 46.80 & 23.09 & 6.87 & 1.29 & 1.25 \\
3 & 47.95 & 21.09 & 6.51 & 1.30 & 1.31 \\
4 & 46.18 & 20.34 & 7.50 & 1.34 & 1.32 \\
5 & 45.74 & 20.00 & 6.42 & 1.35 & 1.33 \\
6 & 45.96 & 19.92 & 7.44 & 1.32 & 1.34 \\
7 & 45.93 & 20.34 & 8.00 & 1.31 & 1.30 \\
8 & 46.65 & 20.64 & 7.71 & 1.33 & 1.31 \\
9 & 46.05 & 19.62 & 6.94 & 1.34 & 1.28 \\
10 & 48.50 & 23.00 & 7.40 & 1.36 & 1.38 \\
11 & 45.89 & 19.88 & 6.74 & 1.32 & 1.31 \\
12 & 45.86 & 16.50 & 7.97 & 1.28 & 1.31 \\
13 & 45.67 & 20.11 & 7.80 & 1.26 & 1.32 \\
14 & 46.18 & 20.13 & 7.88 & 1.30 & 1.34 \\
15 & 46.82 & 20.29 & 8.01 & 1.33 & 1.33 \\
16 & 46.44 & 20.85 & 7.73 & 1.35 & 1.27 \\
17 & 45.94 & 20.04 & 7.00 & 1.30 & 1.31 \\
18 & 46.03 & 19.87 & 7.98 & 1.29 & 1.27 \\
19 & 45.81 & 19.71 & 7.90 & 1.27 & 1.31 \\
20 & 49.14 & 20.26 & 6.86 & & \\
\hline
\end{tabular}

\section{Response surface optimization for enhanced EPS production}

A design model with 20 runs in 1 block was performed and the variables were tested at four levels (Tables 2A and 2B). The statistical significance of the experimental data was checked using Fisher's statistical test for ANOVA, the 3D graphs were also designed. Tables $3 \mathrm{~A}$ and $3 \mathrm{~B}$ showed that the model $p$-values of 0.0053 and 0.0010 for EPS-YO175 and EPS-OF101 were significant. Also, the Model $F$-values of 5.88 and 8.88 for EPS-YO175 and EPS-OF101 imply that the models were significant. In EPS-YO15 and EPS-OF101, the lack-of-fit term was greater than 0.05 which is non-significant relative to the pure error. 
Table 2B The central composite experimental design matrix showing the predicted and actual values of exopolysaccharide from Lactobacillus plantarum OF101. The CCD of the EPS samples.

\begin{tabular}{llllll} 
Run & A & B & C & \multicolumn{2}{c}{ EPS Yield (g/L) } \\
\cline { 5 - 6 } & $\begin{array}{l}\text { Cultivation } \\
\text { time (hr) }\end{array}$ & $\begin{array}{l}\text { Sucrose } \\
\text { concentration }(\mathbf{g})\end{array}$ & $\mathbf{p H}$ & Experimental (E1) & Predicted \\
\hline 1 & 47.00 & 20.00 & 7.00 & 2.17 & 2.16 \\
2 & 49.00 & 16.00 & 8.00 & 2.12 & 2.10 \\
3 & 49.00 & 24.00 & 8.00 & 2.09 & 2.10 \\
4 & 49.00 & 24.00 & 6.00 & 2.06 & 2.10 \\
5 & 45.00 & 24.00 & 6.00 & 2.04 & 2.05 \\
6 & 49.00 & 16.00 & 8.00 & 2.10 & 2.12 \\
7 & 45.00 & 16.00 & 7.76 & 2.08 & 2.14 \\
8 & 45.00 & 16.00 & 6.70 & 2.06 & 2.10 \\
9 & 45.29 & 24.00 & 7.47 & 2.13 & 2.14 \\
10 & 45.84 & 18.92 & 6.98 & 2.14 & 2.15 \\
11 & 47.64 & 23.76 & 7.72 & 2.14 & 2.10 \\
12 & 45.78 & 21.28 & 6.60 & 2.15 & 2.06 \\
13 & 48.16 & 18.03 & 7.24 & 2.11 & 2.10 \\
14 & 47.70 & 23.50 & 7.80 & 2.18 & 2.19 \\
15 & 47.65 & 17.10 & 7.81 & 2.13 & 2.15 \\
16 & 47.10 & 23.34 & 7.40 & 2.12 & 2.10 \\
17 & 47.16 & 22.89 & 7.95 & 2.15 & 2.15 \\
18 & 47.67 & 19.24 & 7.94 & 2.12 & 2.10 \\
19 & 45.11 & 17.10 & 6.70 & 2.09 & 2.08 \\
20 & 47.88 & 23.34 & 6.42 & 2.04 & \\
\hline & & & & & \\
\hline
\end{tabular}

The developed regression model equations describing the relationship between the EPS yield (Y) and the coded values of independent factors; cultivation time (hr) (A), sucrose concentration ( $\mathrm{g}$ ) (B), $\mathrm{pH}(\mathrm{C})$ and their corresponding interactions is described below:

$$
\begin{aligned}
& \mathrm{Y}_{\mathrm{EPS}-\mathrm{YO} 175}=2.15+5.891 \mathrm{E}-003 \mathrm{~A}+0.011 \mathrm{~B}-7.356 \mathrm{E}-003 \mathrm{C}-3.750 \mathrm{E}-003 \mathrm{AB} \\
& +0.011 \mathrm{AC}+6.250 \mathrm{E}-003 \mathrm{BC}-0.013 \mathrm{~A}^{2}-0.011 \mathrm{~B}^{2}-0.013 \mathrm{C}^{2} \\
& \mathrm{Y}_{\mathrm{EPS}-\mathrm{OF} 101}=1.35-0.018 \mathrm{~A}+0.027 \mathrm{~B}+0.019 \mathrm{C}+0.019 \mathrm{AB}+6.250 \mathrm{E}-003 \mathrm{AC} \\
& -0.011 \mathrm{~B}-0.017 \mathrm{~A}^{2}-0.074 \mathrm{~B}^{2}-4.874 \mathrm{E}-003 \mathrm{C}^{2}
\end{aligned}
$$

where Y implies EPS yield ( $\mathrm{g} / \mathrm{L})$.

Three-dimensional response surface plots and contour of EPS yield from L. plantarum YO175 (Figs. 3A-3C) and OF101 (Figs. 4A-4C) illustrate the interactions between the three variables. The curvatures' nature of 3D surfaces gave good interaction between sucrose concentration and cultivation time, $\mathrm{pH}$ and cultivation time, $\mathrm{pH}$ and sucrose concentration.

The optimal values of the independent factors selected for the production of EPS were obtained by solving the regression equation (Eqs. (1)-(2)) using the Expert Design 
Table 3A Analysis of Variance (ANOVA) of quadratic model for production of exopolysaccharide in Lactobacillus plantarum YO175. The ANOVA table generated from the RSM analysis.

\begin{tabular}{lllllll} 
Source & $\begin{array}{l}\text { Sum of } \\
\text { squares }\end{array}$ & df & $\begin{array}{l}\text { Mean } \\
\text { square }\end{array}$ & $\boldsymbol{F}$ value & $\begin{array}{l}\boldsymbol{p} \text {-value } \\
\text { prob }>\boldsymbol{F}\end{array}$ & \\
\hline Model & 9.905 & 9 & 7.21 & 5.88 & 0.0053 & Significant \\
A-Cultivation time & 4.740 & 1 & 4.740 & 2.53 & 0.1425 & \\
B-Sucrose conc. & 1.511 & 1 & 1.511 & 8.08 & 0.0175 & \\
C-pH & 7.389 & 1 & 7.389 & 3.95 & 0.0749 & \\
AB & 1.125 & 1 & 1.125 & 0.60 & 0.4559 & \\
AC & 1.013 & 1 & 1.013 & 5.41 & 0.0423 & \\
BC & 3.125 & 1 & 3.125 & 1.67 & 0.2252 & \\
$\mathrm{~A}^{2}$ & 2.500 & 1 & 2.500 & 13.37 & 0.0044 & \\
$\mathrm{~B}^{2}$ & 1.870 & 1 & 1.870 & 10.02 & 0.0101 & \\
$\mathrm{C}^{2}$ & 3.369 & 1 & 3.369 & 13.37 & 0.0044 & \\
Residual & 1.870 & 10 & 1.870 & & & \\
Lack of fit & 3.369 & 5 & 3.369 & 0.22 & 0.9391 & Not significant \\
Pure error & 1.533 & 5 & 1.04 & & & \\
Cor total & 0.012 & 19 & & & & \\
\hline
\end{tabular}

Notes.

$R$-squared $=0.8412$; Adequate precision $=8.558$.

Table 3B Analysis of Variance (ANOVA) of quadratic model for production of exopolysaccharide in Lactobacillus plantarum OF101. The ANOVA table generated from the RSM analysis.

\begin{tabular}{lllllll} 
Source & $\begin{array}{l}\text { Sum of } \\
\text { squares }\end{array}$ & df & $\begin{array}{l}\text { Mean } \\
\text { square }\end{array}$ & $\boldsymbol{F}$ value & $\begin{array}{l}\boldsymbol{p} \text {-value } \\
\text { prob }>\boldsymbol{F}\end{array}$ & \\
\hline Model & 0.10 & 9 & 0.04 & 8.88 & 0.0010 & Significant \\
A-Cultivation time & 4.663 & 1 & 4.663 & 3.65 & 0.0852 & \\
B-Sucrose conc. & 0.010 & 1 & 0.010 & 7.88 & 0.0186 & \\
C-pH & 4.967 & 1 & 4.967 & 3.89 & 0.0770 & \\
AB & 2.813 & 1 & 2.813 & 2.20 & 0.1688 & \\
AC & 3.125 & 1 & 3.125 & 0.24 & 0.6317 & \\
BC & 1.012 & 1 & 1.012 & 0.79 & 0.3944 & \\
$\mathrm{~A}^{2}$ & 3.982 & 1 & 3.982 & 3.12 & 0.1080 & \\
$\mathrm{~B}^{2}$ & 0.078 & 1 & 0.078 & 61.20 & $<0.0001$ & \\
$\mathrm{C}^{2}$ & 0.13 & 1 & 0.13 & 0.27 & 0.6167 & \\
Residual & 0.013 & 10 & 0.013 & & & \\
Lack of fit & 0.013 & 6 & 0.013 & 70.35 & 0.6252 & Not-significant \\
Pure error & 1.200 & 4 & 0.80 & & & \\
Cor total & 0.11 & 19 & & & & \\
\hline
\end{tabular}

Notes.

$R$-squared $=0.8888 ;$ Adequate precision $=10.789$.

8.0.7.1 software package. The optimal values of the tested variables of $L$. plantarum YO175 were; cultivation time, $48.50 \mathrm{~h}$; sucrose concentration, $23.00 \mathrm{~g} / \mathrm{L}$, and $\mathrm{pH}, 7.40$. Under these conditions, the maximum predicted yield of EPS was $1.38 \mathrm{~g} / \mathrm{L}$ and its experimental yield was $1.36 \mathrm{~g} / \mathrm{L}$. For L. plantarum OF101, the optimal values of the test variables were 

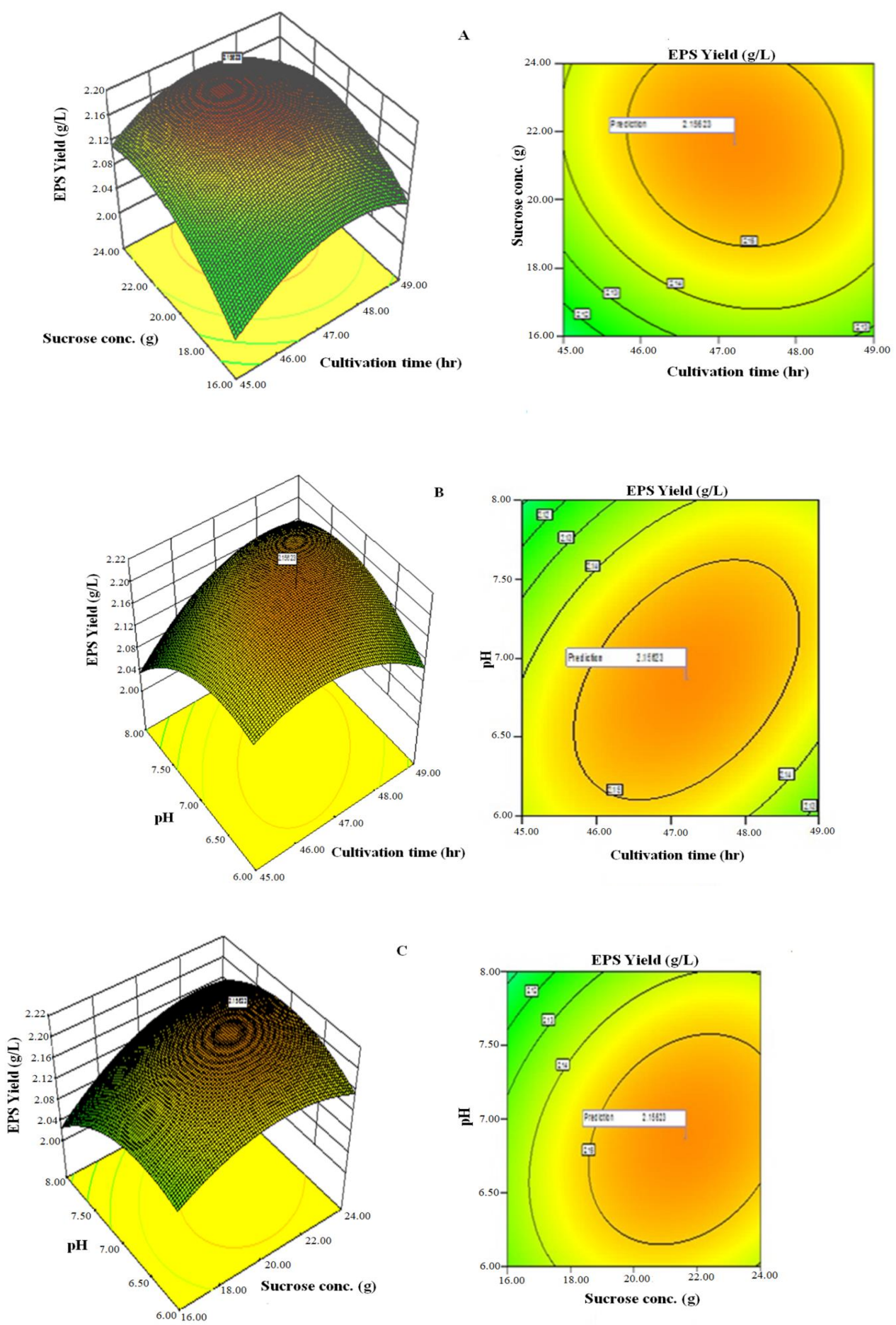

c

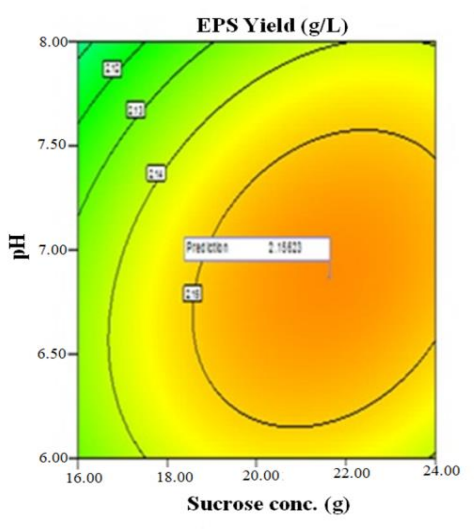

Figure 3 Response surface three-dimensional plots and corresponding contour plots of the three significant variables on EPS yield for Lactobacillus plantarum YO175. (A) Sucrose concentration and cultivation time (B) $\mathrm{pH}$ and cultivation time $(\mathrm{C}) \mathrm{pH}$ and sucrose concentration. 

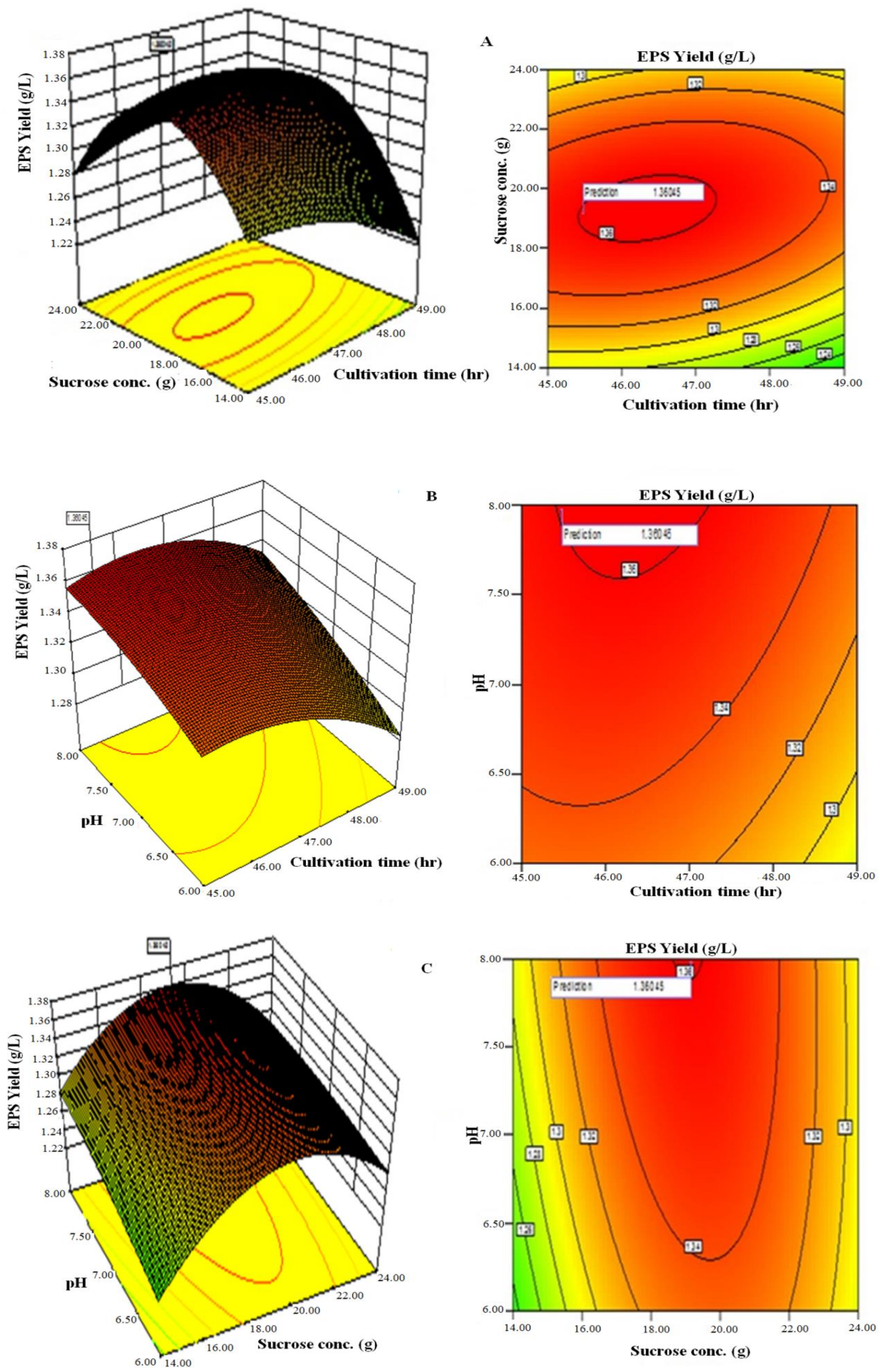

c

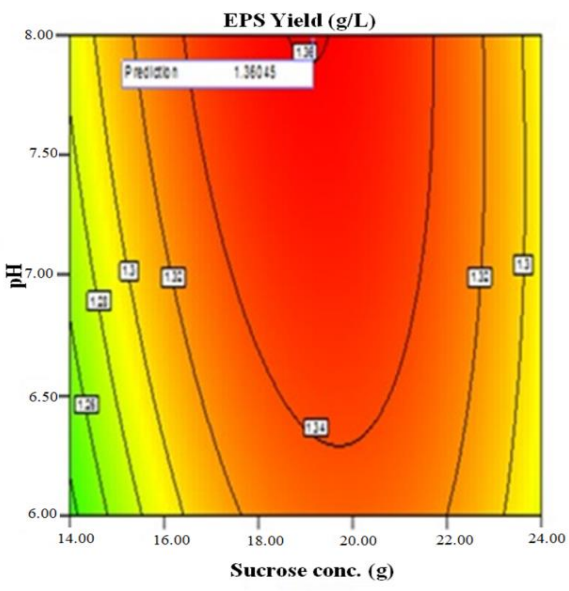

Figure 4 Response surface three-dimensional plots and corresponding contour plots of the three significant variables on EPS yield for Lactobacillus plantarum OF101 (A) Sucrose concentration and cultivation time (B) $\mathrm{pH}$ and cultivation time $(\mathrm{C}) \mathrm{pH}$ and sucrose concentration. 
cultivation time, $48.00 \mathrm{~h}$; sucrose concentration, $23.50 \mathrm{~g} / \mathrm{L}$ and $\mathrm{pH}, 7.50$ and the maximum predicted yield was $2.19 \mathrm{~g} / \mathrm{L}$ and its actual experimental value was $2.18 \mathrm{~g} / \mathrm{L}$.

\section{In vitro determination of antioxidant properties $D P P H$ free radical scavenging activity}

The DPPH scavenging activity observed in the EPS samples and ascorbic acid at concentration of $0.5 \mathrm{mg} / \mathrm{mL}$ was lower than the ones at $4 \mathrm{mg} / \mathrm{mL}$. At $4 \mathrm{mg} / \mathrm{mL}$, the scavenging activity for the ascorbic acid was significantly higher than those found in L. plantarum YO175 (56.9\%) and OF101 (51.2\%) respectively (Table 4).

\section{Superoxide scavenging activity}

The superoxide scavenging activity of purified EPS samples and ascorbic acid are shown in Table 4. As the concentration increases from $0.5 \mathrm{mg} / \mathrm{mL}$ to $4 \mathrm{mg} / \mathrm{mL}$ the scavenging effects also increases; from $23 \%-45.3 \%$ in EPS-OF $101,37.9 \%-83.1 \%$ in ascorbic acid and $43.2 \%-89.4 \%$ in EPS-YO175.

\section{Reducing power activity of EPS}

The reducing power of the EPS sample (s) and ascorbic acid increased with the increase in the concentration levels from $0.5 \mathrm{mg} / \mathrm{mL}$ to $4 \mathrm{mg} / \mathrm{mL}$. The reducing power of the ascorbic acid, EPS-YO175 and EPS-OF101 at $4 \mathrm{mg} / \mathrm{mL}$ concentration are; $(0.91>0.41>0.34)$, no significant differences was observed between the EPS samples, but the result obtained for the ascorbic acid showed that there was significant different from EPS-YO175 and OF101 (Table 4).

\section{Hydroxyl radical scavenging activity}

The hydroxyl radical generated by the Fenton reaction in the system was scavenged by the EPS-YO175, EPS-OF101 and ascorbic acid. Their scavenging effects are shown in Table 4. The two EPS samples exhibited moderate scavenging effect against hydroxyl radical, and EPS-YO175 showing stronger scavenging effect than EPS-OF101. However, ascorbic acid showed higher hydroxyl radical scavenging activity and was significantly different from the EPS samples. At a concentration of $4 \mathrm{mg} / \mathrm{mL}$, the scavenging activity for EPS-YO175, EPS-101, and ascorbic acid was $66.0 \%, 52.3 \%$ and $83.1 \%$ respectively.

\section{DISCUSSION}

Exopolysaccharides produced by strains of Lactobacillus plantarum YO175 and OF101 isolated from traditional fermented cereal beverage on MRS sucrose modified media were investigated. The chemical composition analysis showed that EPS samples contained significant amounts of carbohydrate content and relatively low protein. High carbohydrate content from LAB-EPS has been documented by several researchers (Li et al., 2014; Wang et al., 2015; Imran et al., 2016). Liu et al. (2002) also reported protein content as low as $2.3 \%$ from EPS obtained from the fermentation of kefir grains. Lactic acid is the major metabolic end product of carbohydrate fermentation in LAB. These LAB strains were found to produce LA, and therefore they possess the ability to lower $\mathrm{pH}$ in food which may result in the development of desirable organoleptic properties and inhibition of the pathogenic microorganisms in food, thereby ensuring safety and stability of the final product. 
Table 4 In vitro antioxidant activities of the exopolysaccharides from L. plantarum YO175 and OF101. The antioxidant activities of the EPS samples.

\begin{tabular}{|c|c|c|c|}
\hline $\begin{array}{l}\text { Concentrations } \\
(\mathrm{mg} / \mathrm{mL})\end{array}$ & Ascorbic acid & EPS-YO175 & EPS-OF101 \\
\hline & \multicolumn{3}{|c|}{ DPPH scavenging activity (\%) } \\
\hline 0.5 & $38.7 \pm 0.21^{\mathrm{c}}$ & $22.3 \pm 0.79^{\mathrm{b}}$ & $18.9 \pm 0.66^{\mathrm{a}}$ \\
\hline 1.0 & $47.0 \pm 0.20^{c}$ & $28.3 \pm 0.82^{\mathrm{b}}$ & $21.3 \pm 0.76^{\mathrm{a}}$ \\
\hline 1.5 & $56.1 \pm 0.00^{c}$ & $35.3 \pm 0.30^{\mathrm{b}}$ & $27.4 \pm 1.83^{\mathrm{a}}$ \\
\hline 2.0 & $60.9 \pm 0.40^{c}$ & $39.1 \pm 0.23^{b}$ & $32.8 \pm 0.17^{\mathrm{a}}$ \\
\hline 2.5 & $64.7 \pm 1.47^{c}$ & $46.5 \pm 0.95^{\mathrm{b}}$ & $40.8 \pm 1.56^{\mathrm{a}}$ \\
\hline 3.0 & $72.1 \pm 0.90^{c}$ & $50.7 \pm 0.44^{\mathrm{b}}$ & $47.6 \pm 0.56^{\mathrm{a}}$ \\
\hline 3.5 & $78.3 \pm 1.74^{c}$ & $54.0 \pm 0.00^{\mathrm{b}}$ & $49.8 \pm 0.20^{\mathrm{a}}$ \\
\hline \multirow[t]{2}{*}{4.0} & $82.1 \pm 1.23^{c}$ & $56.9 \pm 1.77^{\mathrm{b}}$ & $51.3 \pm 0.35^{\mathrm{a}}$ \\
\hline & \multicolumn{3}{|c|}{ Superoxide scavenging activity (\%) } \\
\hline 0.5 & $37.9 \pm 0.36^{\mathrm{b}}$ & $43.2 \pm 0.53^{c}$ & $23.0 \pm 0.00^{\mathrm{a}}$ \\
\hline 1.0 & $51.3 \pm 0.70^{\mathrm{b}}$ & $55.7 \pm 0.36^{c}$ & $27.8 \pm 0.35^{\mathrm{a}}$ \\
\hline 1.5 & $57.4 \pm 0.80^{\mathrm{b}}$ & $62.1 \pm 0.56^{c}$ & $31.4 \pm 0.35^{\mathrm{a}}$ \\
\hline 2.0 & $64.3 \pm 0.53^{\mathrm{b}}$ & $69.8 \pm 0.79^{c}$ & $35.7 \pm 0.70^{\mathrm{a}}$ \\
\hline 2.5 & $69.1 \pm 1.05^{\mathrm{b}}$ & $77.6 \pm 0.70^{c}$ & $38.9 \pm 1.08^{\mathrm{a}}$ \\
\hline 3.0 & $74.2 \pm 0.35^{\mathrm{b}}$ & $82.6 \pm 0.56^{c}$ & $41.8 \pm 0.20^{\mathrm{a}}$ \\
\hline 3.5 & $80.4 \pm 0.53^{b}$ & $86.3 \pm 0.70^{c}$ & $42.7 \pm 0.45^{\mathrm{a}}$ \\
\hline \multirow[t]{2}{*}{4.0} & $83.1 \pm 0.17^{\mathrm{b}}$ & $89.4 \pm 0.35^{c}$ & $45.2 \pm 0.20^{\mathrm{a}}$ \\
\hline & \multicolumn{3}{|c|}{ Reducing power activity (Abs $700 \mathrm{~nm}$ ) } \\
\hline 0.5 & $0.33 \pm 0.62^{\mathrm{b}}$ & $0.17 \pm 0.02^{\mathrm{a}}$ & $0.11 \pm 0.00^{\mathrm{a}}$ \\
\hline 1.0 & $0.55 \pm 0.00^{\mathrm{b}}$ & $0.21 \pm 0.02^{\mathrm{a}}$ & $0.19 \pm 0.01^{\mathrm{a}}$ \\
\hline 1.5 & $0.67 \pm 0.04^{\mathrm{b}}$ & $0.25 \pm 0.03^{\mathrm{a}}$ & $0.23 \pm 0.01^{\mathrm{a}}$ \\
\hline 2.0 & $0.71 \pm 0.04^{\mathrm{b}}$ & $0.28 \pm 0.03^{\mathrm{a}}$ & $0.24 \pm 0.03^{\mathrm{a}}$ \\
\hline 2.5 & $0.75 \pm 0.02^{\mathrm{b}}$ & $0.31 \pm 0.02^{\mathrm{a}}$ & $0.26 \pm 0.04^{\mathrm{a}}$ \\
\hline 3.0 & $0.82 \pm 0.03^{c}$ & $0.37 \pm 0.01^{b}$ & $0.28 \pm 0.02^{\mathrm{a}}$ \\
\hline 3.5 & $0.87 \pm 0.11^{\mathrm{b}}$ & $0.39 \pm 0.04^{\mathrm{a}}$ & $0.31 \pm 0.02^{\mathrm{a}}$ \\
\hline \multirow[t]{2}{*}{4.0} & $0.91 \pm 0.03^{c}$ & $0.41 \pm 0.03^{\mathrm{b}}$ & $0.34 \pm 0.01^{\mathrm{a}}$ \\
\hline & \multicolumn{3}{|c|}{ Hydroxyl radical scavenging activity (\%) } \\
\hline 0.5 & $38.7 \pm 0.69^{c}$ & $26.8 \pm 0.70^{\mathrm{b}}$ & $22.0 \pm 0.00^{\mathrm{a}}$ \\
\hline 1.0 & $49.7 \pm 0.61^{\mathrm{c}}$ & $37.6 \pm 0.36^{\mathrm{b}}$ & $27.0 \pm 0.35^{\mathrm{a}}$ \\
\hline 1.5 & $57.4 \pm 0.87^{c}$ & $41.3 \pm 0.61^{\mathrm{b}}$ & $31.2 \pm 1.27^{\mathrm{a}}$ \\
\hline 2.0 & $64.3 \pm 0.61^{\mathrm{c}}$ & $45.8 \pm 0.53^{\mathrm{b}}$ & $37.9 \pm 0.10^{\mathrm{a}}$ \\
\hline 2.5 & $69.1 \pm 0.27^{c}$ & $53.2 \pm 1.59^{\mathrm{b}}$ & $44.7 \pm 0.62^{\mathrm{a}}$ \\
\hline 3.0 & $74.2 \pm 0.82^{c}$ & $57.1 \pm 0.17^{b}$ & $49.2 \pm 0.82^{\mathrm{a}}$ \\
\hline 3.5 & $80.4 \pm 0.60^{c}$ & $62.3 \pm 0.70^{\mathrm{b}}$ & $50.1 \pm 0.17^{a}$ \\
\hline 4.0 & $83.1 \pm 1.39^{c}$ & $66.0 \pm 0.00^{\mathrm{b}}$ & $52.3 \pm 0.30^{\mathrm{a}}$ \\
\hline
\end{tabular}


The analysis of the EPS monosaccharide composition revealed glucose and galactose monomers which indicates that EPS-YO175 is an heteropolysaccharide and EPS-OF101 is an homopolysaccharide. Our result is in agreement with Imran et al. (2016) who reported that the monomer composition in EPS samples can vary among different strains of the same species. Tallon, Bressollier \& Urdaci (2003) reported that L. plantarum EP56 is composed of glucose and galactose. Other researchers have also reported that EPS from L. plantarum are composed of different sugar moieties (Ismail \& Nampoothiri, 2010; Imran et al., 2016).

FT-IR is a useful tool for determining the functional groups in EPS (Wang et al., 2008). The functional groups present in the two EPS samples as determined by FT-IR spectral analysis showed absorption bands of polymeric structure(s). The functional groups with the vibration frequencies when compared with the FT-IR spectra analysis of the other polysaccharides reported in the literature confirmed that the two EPS samples are carbohydrates (Wang et al., 2010). Similar FTIR peak range was observed for L.plantarum YW11 isolated from Tibet kefir and L. helveticus MB2-1 isolated from say ram ropy fermented milk (Li et al., 2014; Wang et al., 2015).

The amounts of EPS produced by microorganisms depend solely on the cultivation conditions and media composition (Wang et al., 2010). Carbon and nitrogen sources, cultivation time, temperature and $\mathrm{pH}$ have been reported to influence growth and production of EPS by LAB (Gandhi, Rayand \& Patel, 1997). Ismail \& Nampoothiri (2010) and Kanmani et al. (2011) reported that at $35^{\circ} \mathrm{C}$ and $\mathrm{pH}$ ranging between 6.5 and 7.0, maximum EPS production was obtained for the EPS producing Lactobacillus and Streptococcus species. The optimum range of cultivation conditions obtained during the production of EPS was similar to those reported by other researchers (Hallemeersch, De Baet \& Vandamme, 2002; Sarwat, Aman \& Ahmed, 2008; Wang et al., 2015; Adesulu-Dahunsi, Sanni \& Jeyaram, 2018). The presence of growth factors such as large quantities of amino acids and short peptides in the yeast extract resulted to enhance EPS production. Liu et al. (2009) also observed that in the presence of yeast extract, high EPS was produced by Paenibacillus polymyca EJS-3. The response surface optimization for enhanced EPS production using RSM and CCD gave good agreement between the experimental and predicted values. This implied that the mathematical models were suitable for the simulation of EPS production in the present study. Many researchers have reported varied amounts of EPS produced by Lactobacillus plantarum species (Zhang et al., 2013; Li et al., 2014).

The in vitro determination of the antioxidant activities increased with increase in their concentrations, no significant difference was observed between the EPS samples. Also, the activities increased in a dose dependent manner as the EPS concentrations increased. Ascorbic acid was found to have higher antioxidant activities when compared with the two EPS samples. The antioxidant potentials displayed by the EPS samples in this study was similar to those reported by other researchers (Sun et al., 2012; Ye et al., 2012; Zhang et al., 2013).

\section{CONCLUSION}

In the present work, the optimization of growth parameters using the statistical methodologies of CCD and RSM for enhanced EPS production by L. plantarum strains 
(YO175 and OF101) isolated from ogi, a Nigerian indigenous fermented food, was studied. The in vitro antioxidant assays showed that the EPS produced by the two L. plantarum strains have strong antioxidant potentials. The characteristics of the EPS produced make it a promising candidate for exploitation in the food industry.

\section{ADDITIONAL INFORMATION AND DECLARATIONS}

\section{Funding}

This work was funded by the World Academy of Sciences (TWAS) and the Department of Biotechnology, India. The funders had no role in study design, data collection and analysis, decision to publish, or preparation of the manuscript.

\section{Grant Disclosures}

The following grant information was disclosed by the authors:

World Academy of Sciences (TWAS).

Department of Biotechnology, India.

\section{Competing Interests}

The authors declare there are no competing interests.

\section{Author Contributions}

- Adekemi Titilayo Adesulu-Dahunsi, Kumaraswamy Jeyaram, Abiodun Isiaka Sanni and Kolawole Banwo conceived and designed the experiments, performed the experiments, analyzed the data, contributed reagents/materials/analysis tools, prepared figures and/or tables, authored or reviewed drafts of the paper, approved the final draft.

\section{DNA Deposition}

The following information was supplied regarding the deposition of DNA sequences:

L. plantarum YO175 and OF101 gene sequences are available at GenBank: numbers KU892395 and KU892393.

\section{Data Availability}

The following information was supplied regarding data availability:

The raw data are provided in the Supplemental Files.

\section{Supplemental Information}

Supplemental information for this article can be found online at http://dx.doi.org/10.7717/ peerj.5326\#supplemental-information.

\section{REFERENCES}

\section{Abdhul K, Ganesha M, Shanmughapriya S, Kanagavel M, Anbarasu K, Natara-} jaseenivasana K. 2014. Antioxidant activity of exopolysaccharide from probiotic strain Enterococcus faecium (BDU7) from Ngari. International Journal of Biological Macromolecules 70:450-454 DOI 10.1016/j.ijbiomac.2014.07.026. 
Adesulu AT, Awojobi KO. 2014. Enhancing sustainable development through indigenous fermented food products in Nigeria. African Journal of Microbiology Research 8:1338-1343 DOI 10.5897/AJMR2013.5439.

Adesulu-Dahunsi AT, Jeyaram K, Sanni AI. 2018. Probiotic and technological properties of exopolysaccharide producing lactic acid bacteria isolated from some cereal-based Nigerian indigenous fermented food products. Journal of Food Control 92:225-231 DOI 10.1016/j.foodcont.2018.04.062.

Adesulu-Dahunsi AT, Sanni AI, Jeyaram K. 2017. Rapid differentiation among Lactobacillus, Pediococcus and Weissella species from some Nigerian indigenous fermented foods. LWT 77:39-44

DOI 10.1016/j.lwt.2016.11.007.

Adesulu-Dahunsi AT, Sanni AI, Jeyaram K. 2018. Production, characterization and In vitro antioxidant activities of exopolysaccharide from Weissella cibaria GA44. LWT 87:432-442 DOI 10.1016/j.lwt.2017.09.013.

Adesulu-Dahunsi AT, Sanni AI, Jeyaram K, Banwo K. 2017. Genetic diversity of Lactobacillus plantarum strains from some indigenous fermented foods in Nigeria. LWT 82:199-206 DOI 10.1016/j.lwt.2017.04.055.

Adesulu-Dahunsi AT, Sanni AI, Jeyaram K, Ojediran JO, Ogunsakin AO, Banwo K. 2018. Extracellular polysaccharide from Weissella confusa OF126: Production, optimization, and characterization. International Journal of Biological Macromolecules 111:514-525 DOI 10.1016/j.ijbiomac.2018.01.060.

Balakrishnan B, Prasad B, Rai AK, Velappan SP, Subbanna MN, Narayan B. 2011. Invitro antioxidant and antibacterial properties of hydrolyzed proteins of delimed tannery fleshings: Comparison of acid hydrolysis and fermentation methods. Biodegradation 22:287-295 DOI 10.1007/s10532-010-9398-0.

Banwo K, Sanni A, Tan H. 2013. Technological properties and probiotic potential of Enterococcus faecium strains isolated from cow milk. Journal of Applied Microbiology 114:229-241 DOI 10.1111/jam.12031.

Dubois M, Gilles K, Hamilton J, Rebers P, Smith F. 1956. Colorimetric methods for determination of sugars and related substances. Annals of Chemistry 28:350-356 DOI 10.1021/ac60111a017.

Gandhi HP, Rayand RM, Patel RM. 1997. Exopolymer production by Bacillus species. Carbohydrate Polymers 34:323-327 DOI 10.1016/S0144-8617(97)00132-X.

Hallemeersch I, De Baet S, Vandamme EJ. 2002. Exopolysaccharides of lactic acid bacteria. Weinheim: Biopolymer, Wiley VCH, 407-429.

Imran MYM, Reehana N, Jayaraj KA, Ahamed AZP, Dhanasekarana D, Thajuddina N, Alharbic NS, Muralitharana G. 2016. Statistical optimization of exopolysaccharide production by Lactobacillus plantarum NTMI05 and NTMI20. International Journal of Biological Macromolecules 93:731-745 DOI 10.1016/j.ijbiomac.2016.09.007.

Ismail B, Nampoothiri KM. 2010. Production, purification and structural characterization of an exopolysaccharide produced by a probiotic Lactobacillus plantarum MTCC 9510. Archive of Microbiology 192:1049-1057 DOI 10.1007/s00203-010-0636-y. 
Kanmani P, Satish kumar R, Yuvaraj N, Paari KA, Pattukumar V, Arul V. 2011. Production and purification of a novel exopolysaccharide from lactic acid bacterium Streptococcus phocae PI80 and its functional characteristics activity in vitro. Bioresource Technology 102:4827-4833 DOI 10.1016/j.biortech.2010.12.118.

Kim Y, Oh S, Yun HS, Kim SH. 2010. Cell-bound exopolysaccharide from probiotic bacteria induces autophagic cell death of tumour cells. Letters in Applied Microbiology 51:123-130.

Li W, Ji J, Rui X, Yu J, Tang W, Chen X, Jiang M, Dong M. 2014. Production of exopolysaccharides by Lactobacillus helveticus MB2-1 and its functional characteristics in vitro. LWT 59:732-739 DOI 10.1016/j.lwt.2014.06.063.

Li Z, Jiang A, Yue T, Wang J, Wang Y, Su J. 2013. Purification and identification of five novel antioxidant peptides from goat milk casein hydrolysates. Journal of Dairy Science 96:4242-4251 DOI 10.3168/jds.2012-6511.

Liu Y, Leigh JW, Brinkmann H, Cushion MT, Rodriguez-Ezpeleta N, Philippe H, Lang BF. 2009. Phylogenomic analyses support the monophyly of Taphrinomycotina, including Schizosaccharomyces fission yeasts. Molecular Biology and Evolution 26:27-34.

Liu JR, Wang SY, Lin YY, Lin CW. 2002. Antitumor activity of milk, kefir and soya milk kefir in tumor bearing mice. Nutrition and Cancer 44:183-187 DOI 10.1207/S15327914NC4402_10.

Lowry OH, Rosebrough NJ, Farr AL, Randall RJ. 1951. Protein measurement with the Folin phenol reagent. Journal of Biological Chemistry 193:265-275.

Pan D, Mei X. 2010. Antioxidant activity of an exopolysaccharide purified from Lactococcuslactis subsp. lactis 12. Carbohydrate Polymers 80:908-914

DOI 10.1016/j.carbpol.2010.01.005.

Patel A, Prajapati JB. 2013. Food and Health Applications of Exopolysaccharides produced by Lactic acid Bacteria. LWT 59:732-739.

Rai AK, Jini R, Swapna HC, Baskaran V, Sachindra NM, Bhaskar N. 2011. Application of native lactic acid bacteria for fermentative recovery of lipids and proteins from fish processing waste: bioactivities of fermentation products. Journal of Aquatic Food Products Technology 20:32-44 DOI 10.1080/10498850.2010.528174.

Salvucci E, LeBlanc JG, Perez G. 2016. Technological properties of Lactic acid bacteria isolated from rawcereal material. LWT 70:185-191 DOI 10.1016/j.lwt.2016.02.043.

Sanni AI, Adesulu AT. 2013. Microbiological and physico-chemical changes during fermentation of maize for masa production. African Journal of Microbiology Research 7:4355-4362.

Sarwat FQ, Aman SA, Ahmed N. 2008. Production and characterization of a unique dextran from an Indigenous Leuconostocmesenteroides CMG713. International Journal of Biological Science 4:379-386.

Savadogo AC, Ouattara AT, Savadogo PW, Barro N, Ouattara AS, Traore AS. 2004. Identification of exopolysaccharides-producing lactic acid bacteria from Burkina Faso fermented milk samples. African Journal of Biotechnology 3:189-194. 
Sun Z, Tian Y, Jia M, Pang L, Deng P, Fan K, Liu X, Jia S, Jia L. 2012. Extraction and in vitro antioxidant activity of exopolysaccharide by Pholiota adiposa SX-01. African Journal of Microbiology Research 6:1869-1876.

Surayot U, Wang J, Seesuriyachan P, Kuntiya A, Tabarsa M. 2014. Exopolysaccharides from lactic acid bacteria: structural analysis, molecular weight effect on immunomodulation. International Journal of Biological Macromolecules 68:233-240 DOI 10.1016/j.ijbiomac.2014.05.005.

Tallon R, Bressollier O, Urdaci CM. 2003. Isolation and characterization of two exopolysaccharides produced by Lactobacillus plantarum EP56. Research in Microbiology 154:705-712 DOI 10.1016/j.resmic.2003.09.006.

Torres-Rodríguez I, Rodríguez-Alegría ME, Miranda-Molina A, Giles-Gómez M, Morales RC, López-Munguía A, Bolívar F, Escalante A. 2014. Screening and characterization of extracellular polysaccharides produced by Leuconostockimchii isolated from traditional fermented pulque beverage. SpringerPlus 3(583):1-14 DOI 10.1186/2193-1801-3-583.

Wang Y, Li C, Liu P, Ahmed Z, Xiao P, Bai X. 2010. Physical characterization of exopolysaccharide produced by Lactobacillus plantarum KF5 isolated from Tibet Kefir. Carbohydrate Polymers 82:895-903 DOI 10.1016/j.carbpol.2010.06.013.

Wang J, Zhang Q, Zhang Z, Li Z. 2008. Antioxidant activity of sulfated polysaccharide fractions extracted from Laminariajaponica. International Journal of Biological Macromolecules 42:127-132 DOI 10.1016/j.ijbiomac.2007.10.003.

Wang J, Zhao X, Tian Z, Yang Y, Yang Z. 2015. Characterization of an exopolysaccharide produced by Lactobacillus plantarum YW11 isolated from Tibet Kefir. Carbohydrate Polymers 125:16-25 DOI 10.1016/j.carbpol.2015.03.003.

Ye S, Liu F, Wang J, Wang H, Zhang M. 2012. Antioxidant activities of an exopolysaccharide isolated and purified from marine Pseudomonas PF-6. Carbohydrate Polymers 87:764-770 DOI 10.1016/j.carbpol.2011.08.057.

Zajsek K, Gorsek A, Kolar M. 2013. Cultivating conditions effects on kefiran production by the mixed culture of lactic acid bacteria imbedded within kefir grains. Food Chemistry 139:970-977 DOI 10.1016/j.foodchem.2012.11.142.

Zhang L, Liu C, Li D, Zhao Y, Zhang X, Zeng X, Yang Z, Li S. 2013. Antioxidant activity of an exopolysaccharide isolated from Lactobacillus plantarum C88. International Journal of Biological Macromolecules 54:270-275 DOI 10.1016/j.ijbiomac.2012.12.037. 